\author{
BARTEOMIEJ KOPCZACKI \\ Uniwersytet Ekonomiczny w Katowicach \\ iD ORCID https://orcid.org/0000-0002-7028-4681
}

\title{
POKOLENIE (BEZ) REWOLUCJI. ŚWIADECTWO NACBOLI
}

\author{
REVOLUTIONARY GENERATION WITHOUT REVOLUTION: \\ THE TESTIMONY OF NAZBOL
}

In this article, the author shows that Eduard Limonov's social and political activity was directed not only at achieving short-term political goals, but also at educating a new generation of Russians. As the head of the National-Bolshevik Party, he was a "godfather" to young people disappointed by the Russian reality of the 1990s and the early years of the presidency of Vladimir Putin. The testimonies in the collections entitled “Лимонка" в тюрьму and “Лимонка" в войну demonstrate that Limonov ultimately achieved his goal of shaping a generation of ideologists ready to sacrifice for their homeland.

Keywords: Limonow, Nazbol generation, National-Bolsheviks, testimonial literature, non-fiction

\section{ПОКОЛЕНИЕ (БЕЗ) РЕВОЛЮЦИИ. СВИДЕТЕЛЬСТВО НАЦБОЛОВ}

Политическая деятельность Эдуарда Лимонова была направлена на воспитание нового поколения молодых россиян. Можно сказать, что Лимонов частично добился успеха: создал Национал-большевистское движение, притягивающее молодых людей, разочарованных в российской действительности 90-х годов и начала XXI столетия. Тексты, входящие в сборники «Лимонка» в тюрьму и «Лимонка» в войну, являются подтверждением тезиса о воспитании Лимоновым поколения готовых на все идейных молодых людей, активно стремящихся изменить Россию, несмотря на обстоятельства. 
Ключевые слова: Лимонов, поколение нацболов, национал-большевизм, литература свидетельства, нон-фикшн

Śmierć Eduarda Limonowa ${ }^{1}$ - prozaika, poety, eseisty, publicysty, charyzmatycznego przywódcy Partii Narodowo-Bolszewickiej - skłania do refleksji na temat jego wpływu na kształtowanie rosyjskiej rzeczywistości lat 90. ubiegłego stulecia oraz początku XXI wieku. Limonow zdołał swoimi działaniami (publicystyka, proza, działalność społeczno-polityczna) odcisnąć ideowe piętno na pokoleniu Rosjan, których młodość przypadła na burzliwy okres upadku ZSRR i powstawania nowego państwa. Część tego pokolenia była pod ogromnym wpływem idei promowanych przez autora To ja, Ediczka (Это я - Эдичка), odnajdując w nich receptę na problemy trapiące współczesną Rosję. Za świadectwo tego pokolenia, urodzonego w Związku Radzieckim i dorastającego w „demokratycznej” Rosji przełomu wieków oraz zaangażowanego $\mathrm{w}$ życie polityczne pod ideowym sztandarem narodowego bolszewizmu, mogą służyć dwa interesujące zbiory tekstów: „Лимонка” в тюрьму („Limonka” w więzieniu) ${ }^{2}$ oraz „Лимонка” в войну („Limonka” na wojnę)3. Oba zbiory powstały pod redakcją Zachara Prilepina, jednego z ideowych uczniów Limonowa ${ }^{4}$.

${ }^{1} 17$ marca 2020 roku.

23. Прилепин, А. Волынец (red.), „Лимонка” в тюрьму. 2000-2011: Сборник, Центрполиграф, Москва 2016.

33. Прилепин (red.), „Лимонка” в войну, Алгоритм, Москва 2016.

${ }^{4}$ Zachar Prilepin od lat uważa się za ideowego ucznia Limonowa. W jednym z odcinków swojego programu „Уроки русского”, nagranym już po śmierci założyciela Partii Narodowo-Bolszewickiej, Prilepin określa go mianem nauczyciela. Co ciekawe, w ostatnim okresie swojego życia (dosłownie przed śmiercią) Limonow bardzo krytycznie wypowiadał się o Prilepinie, negując jego rzekomą przynależność do partii, a także nazywając go frajerem. Zob. m.in.: „Захар Прилепин. Уроки русского”: Урок № 96. Анатомия героя: Эдуард Лимонов, https://www.youtube.com/watch?v=9RTCD0rq0aU (23.09.2020); Э. Лимонов, Что я хочу сказать о Прилепине, https://drugros.ru/slovovozhdia/q94vkvpe (23.09.2020); tegoż, Еще один раз о Прилепине, https:// drugros.ru/slovo-vozhdia/eshchio-odin-raz-o-prilepine (23.09.2020). 


\section{TEORIA POKOLENIA}

Najbardziej rozpowszechnioną te orią pokoleń ${ }^{5}$ jest ta, która została zaproponowana przez dwóch amerykańskich badaczy, Williama Straussa i Neila Howe'a. W swojej klasycznej już książce Generations. The History of America's Future, 1584 to $2069^{6}$ autorzy sugerują nazwać poszczególne pokolenia, uwzględniając wydarzenia historyczne i wybitne postacie $\mathrm{z}$ danego okresu ${ }^{7}$, mające wpływ na formowanie danej generacji. Co więcej, terminologia zaproponowana przez badaczy przeniknęła $\mathrm{z}$ dyskursu naukowego do języka potocznego ${ }^{8}$. Nie sposób odmówić autorom rozmachu przedsięwzięcia - z uznaniem należy spojrzeć na szczegółową analizę każdej generacji. Dla wielu zainteresowanych zagadnieniem pokoleń monumentalizm badań amerykańskich uczonych stanowi zachętę do wykorzystania proponowanego przez nich aparatu metodologicznego w swoich analizach. Jednak pojawiają się i głosy krytyczne. Na przykład na gruncie rosyjskim przeciwko zastosowaniu wprost teorii amerykańskich uczonych wypowiada się m.in. Nikołaj Popow. Twierdzi on, że rozważania autorów Generations... mieszczą się bardziej w ramach popkultury i mają więcej wspólnego

${ }^{5}$ Warto zaznaczyć, że problem badania zjawiska pokolenia jest niezwykle złożony. W dyskursie pokoleniowym krzyżują się różne podejścia metodologiczne oraz nurty filozoficzne, co sprzyja płynności pojęć, ale jednocześnie wymusza stawianie nowych tez i dynamizuje proces rozwoju tej dziedziny badań. Zob. A. Artwińska, M. Fidelis, A. Mrozik, A. Zawadzka, Pożytki z „pokolenia”. Dyskusja o „pokoleniu” jako kategorii analitycznej, „Teksty Drugie” 2016, nr 1, s. $347-366$.

${ }^{6}$ W. Strauss, N. Howe, Generations. The History of America's Future, 1584 to 2069, William Morrow and Company, New York 1991, s. 60-62.

${ }^{7}$ Tamże, s. 84, 279.

${ }^{8}$ Może o tym świadczyć rozpowszechniony zwrot „OK, boomer”. Termin boomer odnosi się w nim do osoby reprezentującej pokolenie boomer (urodzeni w USA w latach 1943-1960). Przytoczony zwrot ma na celu zdeprecjonowanie poglądów boomera jako niedzisiejszych, staromodnych. Zob. tamże, s. 299; Rozstrzygnięcie plebiscytu młodzieżowe słowo roku 2019 komentarz Marka Łazińskiego, https://sjp.pwn.pl/mlodziezowe-slowo-roku/ haslo/Rozstrzygniecie-plebiscytu-mlodziezowe-slowo-roku-2019-komentarzMarka-Lazinskiego;6831654.html (19.09.2020). 
z fantazją niż z rzetelną analizą naukową. Popow zauważa, że metodologia Amerykanów nie może być ekstrapolowana do warunków rosyjskich, choć takie próby są czynione nagminnie (głównie poprzez proste kopiowanie aparatu pojęciowego i umiejscowienie go w rosyjskim procesie historycznym) ${ }^{9}$.

Warto zwrócić uwagę na opis tzw. rosyjskiej sztafety pokoleń zaproponowany przez Wadima Radajewa. Według badacza, w historii Rosji ostatniego stulecia dość łatwo wskazać wydarzenia znaczące, które mogą się stać niepodważalnymi cezurami (Wielka Wojna Ojczyźniana, odwilż, zastój, pieriestrojka i liberalne reformy, stabilizacja). W związku z tym wyszczególnia on następujące rosyjskie pokolenia XX wieku:

- pokolenie mobilizacji (мобилизационное поколение) - urodzeni do 1938 roku; wejście w dorosłość w latach 1941-1956;

- pokolenie odwilży (поколение оттепели); szestidiesiatnicy - urodzeni w latach 1941-1945; dorosłość w latach 1956-1964;

- pokolenie zastoju (поколение застоя) - urodzeni w latach 1947-1967; dorosłość w latach 1964-1984;

- pokolenie reformatorskie (реформенное поколение) - urodzeni w epoce dojrzałego socjalizmu (koniec lat 60. i początek 70.); wejście w dorosłość przypada na okres pieriestrojki i liberalnych reform, tj. 1985-1999;

- pokolenie milenialsów (поколение миллениалов) — urodzeni w okresie reform (1982-2000); okres realizacji przypada na pierwsze lata XXI wieku;

\footnotetext{
${ }^{9}$ Przykładowo: amerykańskie pokolenie ludzi urodzonych w latach 1924-1943 (silent generation - pokolenie milczące) jest, według Popowa, „kolejnym pokoleniem zwycięzców”. Z kolei te same roczniki w ZSRR były pokoleniem brutalnie doświadczonym przez kolektywizację, stalinowskie czystki i krwawą wojenną ofiarę. Stąd można je nazwać generacją zwycięstwa ze łzami w oczach. W rzeczywistości, pomimo egzystowania w tym samym czasie, nie sposób porównać mentalności i systemu wartości obu tych grup. Zob. Н. Попов, Российские и американские поколения XX века: откуда пришли миллениаль?, „Мониторинг общественного мнения: Экономические и социальные перемены” 2018, nr 4, s. 312-313.
} 
- pokolenie Z (поколение Z) - urodzeni na początku XXI wieku ${ }^{10}$.

Należy zwrócić uwagę, że Radajew określa cezury kolejnych pokoleń nie tylko na podstawie roku urodzenia, ale także momentu wejścia w dorosłość. Za innymi badaczami, na których się powołuje, okres wejścia w dorosłość należy umiejscowić pomiędzy 17 a 25 rokiem życia ${ }^{11}$. Oprócz dokonania przekonującej systematyzacji, rosyjski uczony dzieli poszczególne grupy wiekowe na pokolenia radzieckie i postradzieckie. Do pokoleń radzieckich zalicza: pokolenie mobilizacji, odwilży i zastoju. Z kolei pokolenie reformatorskie oraz pokolenie urodzonych w latach 1982-2000 i na początku XXI wieku nazwane są postradzieckimi. Większość mieszkańców Federacji Rosyjskiej stanowią obecnie przedstawiciele trzech ostatnich pokoleń ${ }^{12}$.

Przyjmując optykę zaproponowaną przez Radajewa, nie można zapomnieć o trudnościach wynikających $\mathrm{z}$ interpretacji terminu pokolenie oraz o braku konsensusu w wyborze metodologii badań tego zjawiska, dlatego proponuję uzupełnić teorię pokoleń o rozważania niemieckiego socjologa Karla Mannheima. Jego klasyczny już esej Problem pokoleń (1928) dał podwaliny pod nowoczesne rozumienie terminu pokolenie. Pionierski tekst Mannheima wprowadza do dyskursu pokoleniowego pojęcia, bez których

\footnotetext{
${ }^{10}$ В. Радаев, Миллениаль. Как меняется российское общество, Издательский дом Высшей школы экономики, Москва 2020, s. 47-49.

${ }^{11}$ Tamże, s. 37-39.

${ }^{12}$ Tamże, s. 50. W tym miejscu, uzupełniając wywód Radajewa, warto przytoczyć tezę Michaiła Anipkina mówiącą o tym, że ostatnim radzieckim pokoleniem są osoby urodzone w latach 1971-1973. Badacz argumentuje swoje poglądy następująco: urodzeni w tych latach zdążyli skończyć szkołę i zacząć studia w czasach ZSRR, ich zawodowa aktywność przypada natomiast już na połowę lat 90. Dla badacza pokolenie to żyło na przełomie epok, przetrwało upadek ZSRR, nie mając możliwości wykorzystania szans pojawiających się w procesie ekonomicznej liberalizacji i prywatyzacji (w przeciwieństwie do pokolenia lat 70.). Zob. М. Анипкин, Поколение „лишних людей”: антропологический nортрет последнего советского поколения, „Неприкосновенный запас” 2018, nr 1, https://magazines.gorky.media/nz/2018/1/pokolenie-lishnih-lyudej. html (21.09.2020).
} 
analiza zjawiska generacji byłaby niemożliwa. Właśnie w nim pojawiają się takie sformułowania jak u mocowanie pokoleniowe (więź biologiczna rozumiana jako przynależność do jednego/kilku roczników), powiązania pokoleniowe (przeżywanie tych samych zdarzeń, uczestniczenie w nich) czy wspólnota pokoleniowa (podobna lub taka sama reakcja na wydarzenia $\mathrm{w}$ danym okresie). Ważne w kontekście tematu niniejszego artykułu jest także pojęcie prekursora - człowieka, który w swoim pokoleniu pozostaje w ,izolacji”, lecz wywiera wpływ na pokolenie następne ${ }^{13}$. Jak zauważają jednak Anna Martwińska i Agnieszka Mrozik, wadą teorii niemieckiego socjologa jest stwierdzenie, że poczucie przynależności do jednej generacji przejawia się tylko u przedstawicieli warstw wyższych, najlepiej wykształconych, co z kolei stawia poza nawias klasy niższe ${ }^{14}$.

Pomimo wątpliwości narosłych wokół tezy Mannheima oraz oddalenia czasowego, poglądy socjologa nie uległy przedawnieniu i można wykorzystać wprowadzone przez niego pojęcia do analizy pokolenia nacboli ${ }^{15}$. Niemniej, w moim artykule będę nawiązywał do systematyzacji rosyjskich pokoleń zaproponowanej przez Radajewa.

\section{POKOLENIE WEWNĄTRZ POKOLENIA}

Pokolenie zafascynowane współczesnym narodowym bolszewizmem można umiejscowić w ramach czasowych jedynie umownie. Umocowanie pokoleniowe łączy ze sobą osoby urodzone na przełomie lat 60. i 70. (Radajew nazywa je pokoleniem reformatorskim). Uwzględniając wiek autorów tekstów zgromadzonych w zbiorze

${ }^{13}$ K. Mannheim, Problem pokoleń, w: H. Orłowski (oprac.), Pokolenia albo porządkowanie historii, przeł. I. Drozdowska-Broering, J. Kałążny, R. Żytyniec, Wydawnictwo Nauka i Innowacje, Poznań 2015, s. 110-112, 116.

${ }^{14}$ A. Artwińska, A. Mrozik, O pokoleniach z perspektywy niemieckiej, „Teksty Drugie" 2016, nr 1, s. 255.

${ }^{15}$ Nacbol (ros. нацбол) to potoczna nazwa członków Partii NarodowoBolszewickiej (Национал-большевистская партия). 
„Лимонка" в тюрьму, zauważalne jest rozciągnięcie granicy pokolenia także na urodzonych w pierwszej połowie lat $80 .{ }^{16} \mathrm{Nad}$ wyraz trafne i znaczące jest zamieszczenie na stronie redakcyjnej informacji, że autorzy nie mają jeszcze 40 lat ${ }^{17}$. Jednak wspólne przeżywanie tych samych wydarzeń, uczestnictwo w nich (powiązania pokoleniowe) są niewystarczające, aby mówić o pokoleniu ideowo homogenicznym. Generacja młodych Rosjan doświadczających pieriestrojki, tzw. fatalnych lat 90. (ros. лихие девяностые) oraz pierwszych lat rządów Władimira Putina przyjęła różne postawy wobec otaczającej ją rzeczywistości ${ }^{18}$. Dlatego też uważam, że o wiele ważniejszym od umocowania pokoleniowego, rozumianego jako biologiczna przynależność do danego rocznika, jest zdecydowanie wspólnota pokoleniowa - stąd umowność ram czasowych. Co więcej, pokolenie narodowych bolszewików w znacznej mierze zostało wykreowane przez działalność Limonowa. Jest on sui generis prekursorem, człowiekiem, który nie odegrał większej roli w swoim pokoleniu, wywarł natomiast ogromny wpływ na proces kształtowania kolejnych, młodszych roczników ${ }^{19}$. Sam Limonow już od początku swojej działalności politycznej (jako szef Partii Na-

16 3. Прилепин, А. Волынец (red.), „Лимонка” в тюрьму. 2000-2011..., s. 403-408. Najstarszy autor (Anatolij Tiszyn) urodził się w 1967 roku, najmłodszy (Kiriłł Klienow) - w 1985. Niestety, w drugim z analizowanych zbiorów tekstów nie zawarto informacji o wieku autorów.

${ }^{17}$ Tamże, s. 4.

${ }^{18}$ Jako literacki przykład skrajnych postaw mogą służyć, z jednej strony, bohater Generation P, Wawilen Tatarski, który chętnie wszedł w świat rodzącej się rosyjskiej komercji, z drugiej, Prilepinowski Sańkja, kontestujący rzeczywistość z punktu widzenia narodowo-bolszewickiego ekstremizmu.

${ }^{19} \mathrm{O}$ nad wyraz skomplikowanej i bogatej osobowości Limonowa mogą świadczyć określenia przypisywane mu przez badaczy: „enfant terrible rosyjskiej emigracji” (Przemysław Jan Sieradzan), „parias i heros” (Lucjan Suchanek), „machonacjonalista” (Fabrizio Fenghi). Zob. L. Suchanek, Parias i Heros. Twórczość Eduarda Limonowa, Wydawnictwo Uniwersytetu Jagiellońskiego, Kraków 2001, s. 11-30; P.J. Sieradzan, Aksamitni terroryści. Narodowy bolszewizm w Federacji Rosyjskiej, Dom Wydawniczy „Elipsa”, Warszawa 2008, s. 36-51; F. Fenghi, Making post-Soviet counterpublics: the aesthetics of "Limonka” and the NationalBolshevik Party, „Nationalities Papers” 2017, t. 45, nr 2, s. 185. 
rodowo-Bolszewickiej i partii Inna Rosja ${ }^{20}$ ) mówił o tym, że należy kształtować przyszłe elity, tworzyć generację ludzi oddanych spra$w_{i}{ }^{21}$. Najważniejszym adresatem jego poglądów było środowisko wykluczonych młodych ludzi, tzw. nieformałow (ros. неформалы), wychowanych w cieniu wielkich blokowisk sowieckich ${ }^{22}$. Limonow nazywał ich aktywną mniejszością i upatrywał w tej grupie największy potencjał do realizacji swoich idei ${ }^{23}$. Pomimo sformułowania postulatów adresowanych do rzeszy niezadowolonej ze swojego bytu młodzieży rosyjskiej, narodowi bolszewicy stanowili jedynie grupę (stosunkowo wąską) w obrębie swojego pokolenia ${ }^{24}$. Wydarzeniem konstytuującym powstanie wspólnoty pokoleniowej w ich przypadku nie był wyłącznie burzliwy okres przemian społeczno-politycznych końca lat 80 . i początku lat 90., ale przede wszyst-

${ }^{20} \mathrm{Z}$ formalnego punktu widzenia ugrupowania polityczne zakładane przez Limonowa nigdy nie zostały oficjalnie zarejestrowane. Co więcej, działalność jego obu politycznych projektów - nie tylko Partii Narodowo-Bolszewickiej, ale też partii Inna Rosja (Другая Россия) została zakazana na terytorium Rosji.

${ }^{21}$ P.J. Sieradzan, Aksamitni terroryści..., s. 75-76.

${ }^{22}$ Zob. М. Жаковска, Феномен национал-большевистского движения: идеологический, социальный и культурный аспектьы, „История и современность” 2010, nr 1, s. 202-222.

${ }^{23}$ Tamże, s. 71, 93, 98. Wyczerpująco o ideach reprezentowanych przez partię Limonowa pisał m.in. Przemysław Jan Sieradzan. Za badaczem przywołam najważniejsze postulaty Partii Narodowo-Bolszewickiej: budowa eurazjatyckiego Imperium, antykapitalizm, antyamerykanizm, antybiurokratyzm, wrogość wobec Popperowskiego konceptu społeczeństwa otwartego. Marta Żakowska uważa, że współczesny narodowy bolszewizm jest negatywnie nastawiony wobec triady: kapitalizm, liberalizm, demokracja. Andriej Matiuchin zwraca uwagę na eklektyzm ideowy tego środowiska (synteza komunizmu, anarchizmu, eurazjatyzmu i antyglobalizmu). Zob. P.J. Sieradzan, Aksamitni terroryści..., s. 68-69; М. Жаковска, Феномен национал-большевистского движения..., s. 209; А.В. Матюхин, Радикальные национал-патриотические партии России: процесс становления, „Вестник МГОУ. Серия: История и политические науки” 2015, nr 4, s. 177.

${ }^{24} \mathrm{O}$ niewielkim zasięgu wpływu może świadczyć liczba członków organizacji — 8000 w 2002 roku. Sieradzan natomiast podaje liczbę 22 000. Zob. А. Матюхин, Радикальные национал-патриотические..., s. 178; P.J. Sieradzan, Aksamitni terroryści..., s. 102. 
kim zapoznanie się z poglądami Limonowa i z nim osobiście. Jak zauważa Przemysław Jan Sieradzan, Partia Narodowo-Bolszewicka była w znacznej mierze kontrkulturowym ruchem młodzieży ${ }^{25}$. Z przytoczonych informacji można wysnuć wniosek, że metryka nie stanowi najważniejszego wyznacznika dla badania pokolenia nacboli. Pokolenie narodowych bolszewików to przede wszystkim osoby podzielające poglądy Limonowa. Stanowią oni bowiem wspólnotę przede wszystkim ideową, chociaż rekrutującą się (przynajmniej w początkowym okresie) z pokolenia pieriestrojki ${ }^{26}$.

\section{INNA ROSJA LIMONOWA}

Przywódca Partii Narodowo-Bolszewickiej nie był zwolennikiem manifestów i programów politycznych. Jak zauważa Aleksander Dańda, Limonow nie był doktrynerem przywiązującym wielką wagę do słowa pisanego ${ }^{27}$. Niechęć do pracy intelektualnej, nastawionej na wytwarzanie modeli ideologicznych, stała się główną osią konfliktu (prowadzącego do zakończenia współpracy) z Aleksandrem Duginem, jednym z założycieli współczesnego ruchu narodowych bolszewików. Dla Limonowa od politycznej teorii ważniejsze było działanie i $\mathrm{czyn}^{28}$. Stąd deklarowana m.in. w zbiorze esejów Другая Россия (Inna Rosja) chęć dokonania przemian społecznych drogą rewolucji. Limonow stwierdza, że dla milionów tzw. mar-

${ }^{25}$ Tamże, s. 98-99. Nie można zapominać, że Partia Narodowo-Bolszewicka była w początkowym okresie współtworzona także przez Aleksandra Dugina, którego idee wywarły ogromny wpływ na postulaty i postawy zwolenników partii.

${ }^{26}$ Należy jednak zaznaczyć, że analizowane w dalszej części artykułu teksty świadectwa są pisane głównie przez osoby urodzone w latach 70. i 80. Opisywane w relacjach zdarzenia miały miejsce w pierwszych latach XXI wieku.

${ }^{27}$ A. Dańda, Inna Rosja - alternatywne rozwiązania polityczne i przyszłość Rosji według Eduarda Limonowa. „Przegląd Rusycystyczny” 2012, nr 4 (140), s. $25-71$.

${ }^{28}$ M. Kołakowski, Wojna oczami „nacbola”. Obraz wojny w zbiorze opowiadań „Smrt” Eduarda Limonowa, „Kultury Wschodniosłowiańskie - Oblicza i Dialog" 2019, t. 9, s. 47-57. 
ginałow (ros. маргиналы) i bezprizornych (ros. беспризорные) rewolucja będzie aktem sprawiedliwości społecznej29. Przy czym należy zaznaczyć, że rewolucja nie miałaby na celu jedynie zmiany władzy. Limonow postuluje rewolucję totalną. Przede wszystkim należy zniszczyć tzw. adat ${ }^{30}$, czyli tradycję, w omawianym przypadku - rosyjską. Rosyjski adat wytwarza, według Limonowa, kolejne pokolenia tłustych urzędników rodem z dzieł Nikołaja Gogola, kobiety sędziów z grzywkami zaczesanymi na oczy, ciemny wiejski lud oraz pijanych i brutalnych milicjantów ${ }^{31}$. Na miejscu obecnej Rosji powinno powstać euroazjatyckie Imperium, tworzące nową cywilizację wojowników toczących wojny i uprawiających ziemię, mieszkających w koczowniczych wspólnotach rozsianych na niemalże nieograniczonych przestrzeniach Eurazji ${ }^{32}$. Z tekstów wodza narodowych bolszewików można określić jego jednoznacznie wrogi stosunek do trzech najbardziej opresyjnych instytucji w Rosji. Pierwszą z nich jest rodzina - „wykastrowani” mentalnie ojcowie niszczą duszę wojownika w młodym człowieku; matki i żony potencjalnych rewolucjonistów odciągają ich od walki o lepszą przyszłość w myśl zasady, że lepiej mieć rozbitą głowę w pijackiej bójce, niż być zauważonym na demonstracji33. Kolejną instytucją mającą za zadanie stłamszenie osobowości jest szkoła. Według Limonowa, edukacja formalna trwa zdecydowanie za długo. Wiedza przekazywana w szkole jest mało praktyczna, nieprzydatna. Nauczyciele, będący de facto państwowymi funkcjonariuszami, niczym nadzor-

29 Э. Лимонов, Другая Россия, Центрполиграф, Москва 2015, s 203. Przywoływany zbiór esejów stanowi cenne źródło w badaniach nad działalnością polityczną Limonowa nie tylko ze względu na zawarte w nich treści, ale i uporządkowanie wywodu (teksty wchodzące w skład zbioru są podzielone na 22 tematyczne wykłady).

${ }^{30}$ Limonow zapożyczył to określenie z kultury islamu. Adat to zbiór tradycyjnych zasad, prawo zwyczajowe, regulujące życie społeczne w krajach islamskich na równi z Koranem i prawem szariatu. Zob. hasło: adat, https://encyklopedia. pwn.pl/haslo/adat;3865747 (21.09.2020).

${ }^{31}$ Э. Лимонов, Другая Россия..., s. 54.

${ }^{32}$ Tamże, s. 3-5, 223.

${ }^{33}$ Tamże, s. 6-10. 
cy w więzieniu łamią psychikę ucznia ${ }^{34}$. Trzecim wrogiem Innej Rosji jest aparat państwa rosyjskiego. Administracja państwowa wraz z emerytami oraz klasą średnią (właściwie ludźmi w wieku średnim) dyskryminują młodzież w życiu społecznym. Za przykład takiego stanu rzeczy może służyć poniekąd słuszna uwaga, że osiemnastoletni chłopak jest wystarczająco dorosły, aby walczyć w Czeczenii, lecz za mało dojrzały, aby zostać deputowanym ${ }^{35}$.

Zbiór Другая Россия jest interesujący nie tylko ze względu na zawarte $\mathrm{w}$ nim plany stworzenia nowego eurazjatyckiego Imperium oraz wielokrotnie powtarzane tezy o degeneracji Zachodu, rzekomo dążącego do dominacji nad światem, o upadku rosyjskiego społeczeństwa, przeżartego alkoholizmem i ślepo przywiązanego do zgubnych kulturowych tradycji. Najważniejszym aspektem w wywodach Limonowa jest niekwestionowany, moim zdaniem wręcz chorobliwy, kult młodości. Młodość oraz związana z nią energia życiowa ulega w tekstach niemalże fetyszyzacji. Przywódca partii jako przykład do naśladowania wskazuje hunwejbinów. Dodaje, że rewolucja zawsze jest zwycięstwem „dzieci” nad „ojcami”36. Przywódca Partii Narodowo-Bolszewickiej stwierdza, że rewolucja, której celem jest zniszczenie starej Rosji, może się dokonać tylko dzięki młodym osobom, niezadowolonym ze współczesnego świata. Nasuwa się pytanie, za co mieliby walczyć. Limonow bezceremonialnie konstatuje: młody rewolucjonista będzie się bił za rewolucję seksualną i wielość partnerek w narodowo-bolszewickiej komunie, rodzących nowych partyjnych towarzyszy-wojowników. Pełna swoboda seksualna przyczyni się zatem do wzrostu populacji oraz do rozładowania społecznych nerwic ${ }^{37}$. Nie jestem w stanie stwierdzić, czy tego rodzaju idee miały na celu pozyskanie nowych zwolenników w gronie niespełnionej pod względem seksualnym młodzieży i czy rzeczywiście przełożyły się na

\footnotetext{
${ }^{34}$ Tamże, s. 17-19, 22.

${ }^{35}$ Tamże, s. 28.

${ }^{36}$ Tamże, s. 33, 36- 46.

${ }^{37}$ Tamże, s. 14-15, 146-151. Limonow nie poprzestaje na ogólnikach. Szczegółowo opisuje, kiedy młody mężczyzna ma rozpocząć pożycie seksualne (13 lat) oraz ile dzieci powinna urodzić kobieta (obowiązkowe zachodzenie w ciążę pomiędzy 14 a 35 rokiem życia).
} 
powiększenie szeregów partii. Sądzę jednak, że zaakcentowanie młodości oraz podkreślenie seksualnej strony człowieka wskazuje na to, że Limonow dążył nie tylko do przemian natury politycznej, ale również do holistycznego przekształcenia rzeczywistości. Skrajny radykalizm oraz celowe uproszczenie niektórych kwestii ${ }^{38}$ czy upodmiotowienie młodych mogły być pociągające dla wielu „niespokojnych duchów”, zamieszkujących ciasne mieszkania w przepastnych rosyjskich blokowiskach.

\section{NARODOWO-BOLSZEWICKIE ŚWIADECTWO}

Termin literatura świadectwa w naszym kręgu kulturowym może kojarzyć się jednoznacznie z tematyką Zagłady. Jednakże, jak sugeruje Anna Ciarkowska, literatura świadectwa obejmuje o wiele większy zbiór tekstów. Do tej formy opowiadania o przeżywaniu wydarzeń historycznych można zaliczyć także relacje dotyczące każdego zjawiska w życiu społecznym ${ }^{39}$. W swoich rozważaniach Ciarkowska podkreśla dwie niezwykle istotne kwestie związane $\mathrm{z}$ literaturą świadectwa. Pierwszą $\mathrm{z}$ nich jest relatywizm doboru opisywanych zdarzeń (każde z nich może być istotne dla osoby świadczącej); drugą stanowi podmiotowość świadka. Dla badaczki najważniejszym czynnikiem konstytuującym literaturę świadectwa jest wola przekazania prawdy o danym wydarzeniu przez jego uczestnika ${ }^{40}$.

Pojawia się zatem pytanie o typologię gatunkową tychże świadectw. Maria Delaperrière zauważa, że literatury świadectwa nie można utożsamiać z autobiografią. Decyduje o tym podrzędność osoby świadka w stosunku do opisywanych zdarzeń ${ }^{41}$. Wydaje się

${ }^{38}$ Limonow sam stwierdza, że uprościł swój wywód, aby lepiej wpłynąć na młodego czytelnika. Tamże, s. 137.

${ }^{39}$ A. Ciarkowska, Między doświadczeniem a wydarzeniem. O zobowiązaniach świadka, „Zagadnienia Rodzajów Literackich” 2019, t. 62, z. 1, s. 59.

${ }^{40}$ Tamże, s. 58, 61 .

${ }^{41}$ M. Delaperrière, Świadectwo jako problem literacki, „Teksty Drugie” 2013, nr 3, s. 62 . 
to jednak zbyt dużym uproszczeniem. Ciarkowska słusznie zauważa, że świadectwo zrodzone $\mathrm{z}$ doświadczenia może być wyrażone przy pomocy zróżnicowanych form gatunkowych, niejasnych pod względem typologicznym ${ }^{42}$. Stawia to pod znakiem zapytania nie tylko próbę klasyfikacji gatunkowej tego typu tekstów, ale także samo rozumienie pojęcia świadek. Czy zawsze figura świadka musi być podrzędna wobec przekazu? Czy świadczący jest neutralny i koncentruje się wyłącznie na przekazaniu obiektywnej prawdy? te pytania zadaje m.in. Agnieszka Dauksza, konstatując, że świadek nie jest bezstronny, obiektywny, zawsze jest zaangażowany nie tylko poprzez bezpośrednie uczestnictwo, ale także poprzez obserwację czy zaniechanie ${ }^{43}$. W swoim innym tekście Dauksza niejako dekonstruuje obiektywizm instytucji świadka. Badaczka stawia radykalne tezy, pytając chociażby o motywację przedstawienia świadectwa, o to, jakie przesłanki stoją za świadkiem i jego świadectwem, co ma na celu dane świadectwo, kto je rejestruje i gdzie ono jest archiwizowane. Zaznacza, że świadczenie bywa „aktem emancypacji, zaangażowania, mistyfikacją, manipulacją, prowokacją, awansem społecznym - w jego spektrum zawiera się cały repertuar możliwych strategii”" ${ }^{4}$. Badaczka przywołuje również wywodzącą się jeszcze ze starożytności kategoryzację świadków: martys - męczennik, testis - świadek niezaangażowany w spór, superstes - ten, który coś przeżył i może zaświadczyćc ${ }^{45}$.

Uważam, że zbiór świadectw i relacji członków Partii Narodowo-Bolszewickiej ma jednoznacznie polityczny wydźwięk i służy promowaniu konkretnej ideologii. Bohaterowie-autorzy tekstów nie ukrywają swoich poglądów politycznych ani swojego stosunku do aparatu władzy. Prezentują wyrazistą linię ideologiczną. Można ich określić mianem superstes (piszą o swoich przeżyciach

${ }^{42}$ A. Ciarkowska, Między doświadczeniem..., s. 58.

${ }^{43}$ A. Dauksza, Świadek: jak się staje, czym jest?, w: tejże, K. Koprowska (red.), Świadek: jak się staje, czym jest?, Instytut Badań Literackich PAN, Warszawa 2019, s. 8.

${ }^{44}$ A. Dauksza: Ustanawianie świadka, „Teksty Drugie” 2018, nr 3, s. 71, 74-75, 95.

45 Tamże, s. 166. 
i doświadczeniach). Ich świadectwo może być odbierane jako manifest pożądanych w tym środowisku (pokoleniu) postaw. Redaktor obu tomów, Zachar Prilepin, w posłowiu pisze wprost, że jest to świadectwo „najlepszych ludzi z całego pokolenia”, walczących za wolność społeczeństwa, uprawiających realną działalność polityczną w czasach, gdy większość Rosjan dała się uwieść PR-owym sztuczkom. Prilepin przyrównuje więzienne przejścia nacboli z Gułagiem. Puentuje: uczcie się od nich, jak należy walczyć o wolnośćc ${ }^{46}$.

\section{NARODOWI BOLSZEWICY „ZA KRATKAMI”}

Najczęściej poruszanym tematem w tekstach jest rosyjski (ale także łotewski i ukraiński - w zależności od miejsca skazania i zamieszkania nacboli) system penitencjarny. Z relacji wynika jedno: nie jest to przestrzeń służąca resocjalizacji. Areszty i więzienia przedstawione są zazwyczaj jako miejsca brudne i śmierdzące: brak w nich czystej pościeli ${ }^{47}$, cele są przepełnione, zawszone ${ }^{48}$ i panuje w nich zaduch ${ }^{49}$. Nadmierne przeludnienie ma swoje źródło w funkcjonowaniu rosyjskiego systemu sprawiedliwości. Dmitrij Bachur świadczy, że na 70 więźniów w jego celi jedynie 10-15 siedzi „za coś” (np. za posiadanie niewielkiej ilości narkotyków), i dodaje, że sprawy tego typu często są przez milicjantów preparowane $^{50}$. Pozostali są skazywani jedynie w celach sprawozdaw-

46 3. Прилепин, Послесловие, w: tegoż, А. Волынец (red.), „Лимонка” в тюрьму. 2000-2011..., s. 397-402.

${ }^{47}$ Д. Бахур, Бутырка, w: 3. Прилепин, А. Волынец (red.), „Лимонка” в тюрьмy. 2000-2011..., s. 8. Teksty analizowane w tej części artykuły pochodzą ze zbioru „Лимонка” в тюрьму. 2000-2011... Autora, tytuł tekstu oraz stronę podaję w przypisie.

${ }^{48}$ А. Гребнев, Kpecmbl, s. 225.

${ }^{49}$ А. Голубович, Из писем на волю, s. 106.

${ }^{50}$ Д. Бахур, Бутырка..., s. 9; Р. Худаев, Быть готовым ко всему!, s. 15. 
czo-statystycznych ${ }^{51}$. Obsługa więzień nie reprezentuje wysokiego poziomu wyszkolenia: strażnicy piją na służbie, a konwojenci okradają więźniów $\mathrm{z}$ ich prywatnych rzeczy przed wejściem do zony ${ }^{52}$. Pokrzywdzonymi przez system penitencjarny wydają się nie tylko więźniowie. Maksym Gromow zastanawia się, czy odbywający służbę młodzi podoficerowie są w stanie wrócić do "normalnego" cywilnego życia po całym dniu pracy, której istotą jest gnębienie więźniów i prowokowanie konfliktów między nimi („Как они уходили от ежедневной крови, погружаясь в мирную жизнь жён и матерей?") $)^{53}$.

Chociaż więzienie jest „domem szaleńców” (ros. дурдом) ${ }^{54}$, miejscem, gdzie logika nie obowiązuje ${ }^{55}$, i które rządzi się swoimi własnymi, często niepisanymi zasadami, do których należy się dostosować, członkowie partii potrafią się odnaleźć w jego specyficznej rzeczywistości. Siergiej Sołowiej pisze o prostych regułach więziennych, takich jak dbanie o higienę, okazywanie wdzięczności za nawet najdrobniejsze przysługi ze strony współwięźniów. Najlepiej jest też unikać hazardu i zakładów ${ }^{56}$. Zwolennicy narodowego bolszewizmu są więźniami nietypowymi. Opisując swój pobyt w zakładach karnych, dają świadectwo nie tylko o panujących „za kratkami” warunkach, ale także udzielają bardzo konkretnych rad partyjnym towarzyszom, jak zachowywać się w trakcie procesu oraz w czasie odbywania zasądzonej kary. $\mathrm{Na}$ przykład Rusłan Chudajew przedstawia procedurę przesłuchania i podpowiada, jak „zdobyć” największą ilość śladów pobicia (jest to przydatne w sądzie). Radzi też, aby dokładnie czytać akta sprawy i wyszukiwać nieścisłości (co nie jest trudne wobec lekceważącego stosunku służb do swojej pracy $)^{57}$. O przygotowaniu się

\footnotetext{
${ }^{51}$ А. Гребнев, Kpecmol, s. 224.

${ }^{52}$ А. Голубович, Из писем на волю, s. 116; Д. Бахур, Бутырка..., s. 8.

${ }^{53}$ М. Громов, Отрыєви из ненаписанной книги, s. 189.

${ }^{54}$ Н. Чернова, Дембельский альбом Натальи Черновой, s. 266.

${ }^{55}$ А. Голубович, Из писем на волю, s. 106.

${ }^{56}$ С. Соловей, День первыци, s. 27.

${ }^{57}$ Р. Худабаев, Быть готовым ко всему!, s. 16-17.
} 
do głodówki oraz o tym, jak ją należy prowadzić, aby osiągnąć swoje cele pisze z kolei Siergiej Sołowiej ${ }^{58}$. Z relacji nacboli wynika, że funkcjonariusze aparatu sprawiedliwości nie radzą sobie z więźniami politycznymi. Nie wiedzą, w jaki sposób ich skłonić do współpracy, co jest o wiele łatwiejsze w przypadku pospolitych kryminalistów. W trakcie przesłuchania jeden ze śledczych mówi do nacbola: „Были 6 вы уголовниками, мы бы давно уже подход нашли. А вы идейные... как с такими работать - не понимаю" ${ }^{59}$. Członkowie partii mają także odwagę upomnieć się o swoje prawa, wynikające $\mathrm{z}$ regulaminu, i wygrać walkę $\mathrm{z}$ administracją zakładu karnego ${ }^{60}$.

W omawianych świadectwach nie brakuje ideowych deklaracji. Kara pozbawienia wolności wzmacnia członków partii. Jak twierdzi Siergiej Fomczenkow, „[в] общем, тюрьма - это хорошая школа жизни. Нас она не сломила, а только укрепила в уверенности нашей победы” ${ }^{1}$. Swoich czynów nie żałuje Anna Petrenko, skazana na 3 lata kolonii karnej: „Я знаю, что я права. Я определилась уже в этой жизни и расставила все акценты. Я знаю цену своим поступкам и готова ее платить" 2 . Osadzeni zwolennicy Limonowa przedstawiają się jako prawdziwi rewolucjoniści, wierni rewolucyjnemu etosowi. Jeden $\mathrm{z}$ nich, przebywający $\mathrm{w}$ łotewskim więzieniu, stwierdza, że udawanie chorego psychicznie jest niegodne rewolucjonisty: „мы не зеки, мы революционеры"63.

W zakładach karnych trwa walka polityczna. Jewgienij Nikołajew nie okazuje żadnego współczucia dla osadzonego eksbiznesmena, ukaranego przez współwięźniów za łamanie zasad życia w celi (i zaprzestanie płacenia łapówek załodze więzienia). Brak empatii

\footnotetext{
${ }^{58}$ C. Соловей, Голодовка, s. 29-33.

${ }^{59}$ В. Тюрин, Как с таким работать - не понимаю, s. 331.

${ }^{60}$ М. Громов, Отрывки из ненаписанной книги, s. 168.

${ }^{61}$ С. Фомченко, Тюрьма, s. 38.

${ }^{62}$ А. Петренко, Эстакада, s. 44.

${ }^{63}$ Р. Крумголд, Экспертиза, s. 84-85.
} 
tłumaczy klasową nienawiścią ${ }^{64}$. W wielu tekstach świadectwach dostrzec można wrogość wobec tzw. liberałów. Najmocniej wybrzmiewa ona w słowach cytowanego już Grebniewa. Chociaż liberałowie szczycą się zniesieniem kary śmierci, atmosfera rosyjskich więzień sprzyja samobójstwom. Rosyjscy demokraci, próbując nieudolnie naśladować rozwiązania charakterystyczne dla zachodniego systemu penitencjarnego, tworzą przestrzeń bezprawia na kształt obozu koncentracyjnego ${ }^{65}$.

\section{NARODOWO-BOLSZEWICKIE PODRÓŻE}

Teksty ze zbioru „Лимонка” в войну nie stanowią jedynie prostej relacji z podróży. Głównym celem autorów nie jest charakterystyczne dla literatury podróżniczej zapoznanie czytelnika z realiami życia w innych krajach, lecz manifestacja swojej pozycji ideowej. Ostrze krytyki skierowane jest przeciwko współczesnej Rosji oraz szeroko pojętemu Zachodowi. Szlak nacboli wyznacza także symboliczne granice Imperium (w przypadku byłych republik radzieckich). Wiele tekstów zostało opublikowanych pod pseudonimami.

Jednym z przystanków na trasach nacboli jest Kaukaz. Na przykład Abchazja to idealne miejsce dla realizacji idei Innej Rosji. W tym kraju poważa się Limonowa i jego zwolenników za pomoc w wojnie przeciwko Gruzji. Stan demokracji jest lepszy niż w Ro$\mathrm{sji}^{66}$. Azerbejdżan $\mathrm{z}$ kolei jest przedstawiony jako skorumpowana republika ze słabą gospodarką, okradana przez własny rząd ${ }^{67}$.

Andriej Siwow dzieli się swoimi spostrzeżeniami dotyczącymi Iranu. Zauważa, że kraj ten, w przeciwieństwie do Rosji, rozwija się we właściwym kierunku. Pochwala państwowy charakter

${ }^{64}$ Е. Николаев, Дорогая пропажа, s. 59.

${ }^{65}$ А. Гребнев, Kpecmbl, s. 224.

${ }^{66}$ А. Дмитрев, А. Зыков, Сухуми-Цхинвали, w: „Лимонка” в тюрьму..., s. 64. Teksty analizowane w tej części artykuły pochodzą ze zbioru „Лимонка” в тюрьму... Autora, tytuł tekstu oraz stronę podaję w przypisie.

${ }^{67}$ А. Сивов, Азербайджан, s. 78. 
gospodarki i socjalistyczne reformy. Według autora, rosyjskie media, mówiąc o Iranie, powtarzają zachodnią propagandę, utrwalając negatywny stosunek do kraju, w którym funkcjonuje demokratyczny system wielopartyjny ${ }^{68}$. „Obiektywizm” rosyjskich środków masowego przekazu jest także krytykowany w innym tekście Siwowa. Będąc w Kurdystanie, nie widzi on ani jednego z rosyjskich reporterów "demokratycznej prasy” - wolą oni przebywać w Stambule albo Ankarze i zmyślać informacje o Kurdystanie. Siwow jest pod wrażeniem tureckich stróżów prawa napotykanych na ulicach. Tureccy żołnierze i policjanci, w przeciwieństwie do swoich rosyjskich kolegów, świetnie wyglądają i potrafią walczyć. Może dlatego, że nie muszą budować oficerskich dacz ${ }^{69}$. Proceder wykorzystywania żołnierzy do tego typu prac opisuje z kolei porucznik Szeringer. Zamiast szkolenia bojowego odrabiają "pańszczyznę", a następnie są wysyłani do Czeczenii. Rezultat wysłania niewyszkolonych ludzi do walki jest łatwy do przewidzenia ${ }^{70}$.

Osobne miejsce w świadectwach zajmuje Irak. Według autorów wokół konfliktu panuje zmowa zachodnich mediów (przekupionych przez USA - współczesnego Minotaura ${ }^{71}$ ), tworzących wirtualny świat narracji o wojnie ${ }^{72}$. Najwięcej relacji z Iraku przekazuje autor piszący pod pseudonimem Lawrence Mezopotamski. Z pozycji podróżnika-włóczęgi dzieli się wskazówkami, w jak sposób dostać się do Iraku i dołączyć do partyzantów walczących przeciwko wojskom NATO. Radzi on, by nauczyć się podstaw arabskiego, poznać obyczaje ludności, dobrze chronić swoje dokumenty i ubrać się jak miejscowi ${ }^{73}$. Przemierzając Irak, współczesny „Lawrence z Arabii” zauważa wiele negatywnych zjawisk oraz krytykuje nieporadność

\footnotetext{
${ }^{68}$ Tegoż, Иран, s. 85-90.

${ }^{69}$ Tegoż, Курдистан, s. 104-106.

${ }^{70}$ Л-т Шерингер, Наши учителя, s. 195.

${ }^{71}$ В. Ильин, Уроки Ирака, s. 261.

${ }^{72}$ А. Сивов, Первые поражения оккупационного корпуса в Ираке, s. 256-257.

${ }^{73}$ Л. Месопотамский, Как поехать в Ирак на джихад?, s. 46-58.
} 
wojsk okupacyjnych. Bagdadem wstrząsają zamachy i porwania ${ }^{74}$, a w całym kraju, kontrolowanym de facto przez partyzantów, panuje chaos ${ }^{75}$. Rosyjski podróżnik przewiduje zwycięstwo partyzantów, ponieważ „винтовка, как известно, рождает власть”76. Żołnierze międzynarodowej dywizji są dla niego wyłącznie najemnikami z bananowych republik Europy Środkowo-Wschodniej, którzy zachowują się jak SS-mani ${ }^{77}$.

Zajęcie Krymu i wojna na wschodzie Ukrainy wzbudziła zainteresowanie nacboli. Środowisko skupione wokół idei narodowo-bolszewickich przyjęło rosyjskie zaangażowanie w konflikt na Ukrainie nader pozytywnie. Okazuje się, że wielu tzw. limonowców aktywnie uczestniczyło (uczestniczy) w wojnie. Jednym z nich jest Dmitrij Kolesnikow, który ochraniał lokale wyborcze w czasie krymskiego referendum, a następnie jako ochotnik walczył w Donbasie ${ }^{78}$. Benes Ajo, członek łotewskiej komórki partii Inna Rosja, w pełni poparł przemiany polityczne na Krymie i razem ze swoimi rosyjskimi towarzyszami z partii wstąpił w szeregi krymskiej samoobrony. Następnie udał się do Doniecka i agitował przeciwko faszystowskiemu przewrotowi na Ukrainie $^{79}$. W bezpośrednich walkach w Donbasie, a w szczególności w bitwie pod Debalcewem również nie zabrakło nacboli. O niezwykłej motywacji i męstwie członków partii wypowiada się wiceprzewodniczący Innej Rosji. Według niego walczą oni „отчаянно”"

$\mathrm{Z}$ relacji autorów wyłania się obraz pełnej solidarności Rosjan z walczącym Donbasem. Na wpół legalnie z rosyjskich szpitali przekazywane są lekarstwa ${ }^{81}$, a na wschodnią Ukrainę przyjeżdżają

${ }^{74}$ Tegoż, Будни Багдада, s. 272.

75 Tegоż, Ирак. Война, s. 262-263.

${ }^{76}$ Tegoż, Иракский джихад, s. 270.

${ }^{77}$ Tеgоż, Базар для карателей, s. 240.

${ }^{78}$ Д. Колесников, Колесо, s. 357-360.

${ }^{79}$ Б. Айо, Из приключений Бенеса Айо, s. 392, 395.

80 „Новороссия будет освобождена”. Беседовал Захар Прилепин, w: 3. Прилепин (red.), „Лимонка” в войну..., s. 411.

${ }^{81}$ Генри О., Случай в глубоком тылу, s. 386-387. 
niezwykli ochotnicy z Moskwy: technik dentystyczny, programista $^{82}$ i pediatra ${ }^{83}$. Jeśli wierzyć relacjom, walka zbrojna w szeregach wojsk dwóch samozwańczych republik jest odbierana przez zwykłych Rosjan pozytywnie ${ }^{84}$.

\section{KONKLUZJA}

Doświadczenia opisane w świadectwie narodowych bolszewików nie są charakterystyczne dla całego pokolenia pieriestrojki. Limonow był człowiekiem, który wychował swoje pokolenie nacboli. Potrafił on zwerbować młodych ludzi, przekonać do swoich idei oraz pobudzić do radykalnych działań. Jest to interesujące, ponieważ częstą barierę pomiędzy poszczególnymi pokoleniami stanowią różnica wieku i wynikające $\mathrm{z}$ niej wzajemne niezrozumienie. Panuje powszechne przekonanie o tym, że młodość jest radykalna, starość natomiast - konserwatywna. Działalność Limonowa całkowicie przeczy temu stereotypowi. Fakt utworzenia przez Limonowa zdyscyplinowanej grupy politycznej i kontrkulturowej dowodzi niezaprzeczalnej umiejętności komunikowania się Limonowa z młodym pokoleniem. Skupieni wokół Limonowa ludzie, tworzący między sobą więź nie tylko rocznikową, ale przede wszystkim ideologiczną, stali się symbolem radykalnego sprzeciwu wobec przemian zachodzących w Rosji po upadku ZSRR. Idea współczesnego narodowego bolszewizmu, polegająca na połączeniu wątków imperialnych, socjalistycznych i rewolucyjnych, była (jest) alternatywą dla oficjalnego dyskursu władzy, tak quasi-demokratycznej z czasów rządów Borysa Jelcyna, jak i autorytarnej Władimira Putina. Niewielki zasięg zjawiska łączył się ze spektakularnością wyczynów narodowych bolszewików ${ }^{85}$. Głoszona przez nich idea rewolucji nie

\footnotetext{
${ }^{82}$ Шмель, Органы, s. 389.

${ }^{83}$ Печень, Док, s. 353-354.

${ }^{84}$ С. Скляров, Бери и делай, s. 355-356.

${ }^{85}$ Było to m.in.: obrzucenie pomidorami sekretarza generalnego NATO w czasie szczytu w Pradze (2002), okupacja części gmachu Ministerstwa Sprawiedliwości
} 
znalazła swojego odzwierciedlenia w przemianach społeczno-politycznych w Rosji. Pokolenie w pokoleniu nie osiągnęło swoich politycznych celów. Narodowo-bolszewicka Rosja „potencjalna” nadal przegrywa z Rosją , aktualną" (Moscowią) ${ }^{86}$.

\section{REFERENCES}

Anipkin, Mikhail. "Pokoleniye 'lishnikh lyudey:' antropologicheskiy portret poslednego sovetskogo pokoleniya." Neprikosnovennyy zapas, no. 1, 2018, https://magazines.gorky.media/nz/2018/1/pokolenie-lishnih-lyudej.html. Accessed 23 Sep. 2020 [Анипкин, Михаил. “Поколение 'лишних людей:' антропологический портрет последнего советского поколения." Неприкосновенный запас, № 1, 2018, https://magazines.gorky.media/nz/2018/1/ pokolenie-lishnih-lyudej.html. Дата обращения: 21 сентября 2020].

Artwińska, Anna, Fidelis, Małgorzata, Mrozik, Agnieszka, Zawadzka, Anna, "Pożytki z 'pokolenia.' Dyskusja o 'pokoleniu' jako kategorii analitycznej.' Teksty Drugie, no. 1, 2016: 347-366.

Artwińska, Anna, Mrozik, Agnieszka. "O pokoleniach z perspektywy niemieckiej." Teksty Drugie, no. 1, 2016: 253-263.

Ciarkowska, Anna. "Między doświadczeniem a wydarzeniem. O zobowiązaniach świadka." Zagadnienia Rodzajów Literackich, vol. 62, z. 1, 2019: 57-66.

Dańda, Aleksander, „Inna Rosja - alternatywne rozwiązania polityczne i przyszłość Rosji według Eduarda Limonowa." Przegląd Rusycystyczny, no. 4 (140), 2012: 52-71.

Dauksza, Agnieszka. "Świadek: jak się staje, czym jest?" Świadek: jak się staje, czym jest? Ed. Dauksza, Agnieszka, Koprowska, Karolina. Warszawa: Instytut Badań Literackich PAN, 2019.

Dauksza, Agnieszka. "Ustanawianie świadka." Teksty Drugie, no. 3, 2018: 69-96.

Delaperrière, Maria. "Świadectwo jako problem literacki." Teksty Drugie, no. 3, 2013: 59-70.

Fenghi, Fabrizio. "Making post-Soviet counterpublics: the aesthetics of 'Limonka' and the National-Bolshevik Party." Nationalities Papers, vol. 45, no. 3, 2017: 182-205.

Kołakowski, Michał. "Wojna oczami 'nacbola.' Obraz wojny w zbiorze opowiadań 'Smrt' Eduarda Limonowa." Kultury Wschodniostowiańskie - Oblicza i Dialog, vol. 9, 2019: 47-57.

FR (2003), wywieszenie w budynku hotelu Rossija w Moskwie (naprzeciwko Kremla) transparentu z żądaniem dymisji prezydenta Putina. Zob. P.J. Sieradzan, Aksamitni terroryści..., s. 118-122.

${ }^{86}$ Tamże, s. 95. 
Limonov, Eduard. “Chto ya khochu skazat' o Prilepine.” https://drugros.ru/slovovozhdia/q94vkvpe. Accessed 23 Sep. 2020 [Лимонов, Эдуард. "Что я хочу сказать о Прилепине." https://drugros.ru/slovo-vozhdia/q94vkvpe. Дата обращения: 23 сентября 2020].

Limonov, Eduard. Drugaya Rossiya. Moskva: Tsentrpoligraf, 2015 [Лимонов, Эдуард. Другая Россия. Москва: Центрполиграф, 2015].

Limonov, Eduard. "Yeshche odin raz o Prilepine." https://drugros.ru/slovo-vozhdia/eshchio-odin-raz-o-prilepine. Accessed 23 Sep. 2020 [Лимонов, Эдуард. “Еще один раз о Прилепине." https://drugros.ru/slovo-vozhdia/eshchio-odin-raz-o-prilepine. Дата обращения: 23 сентября 2020].

"Limonka" v tyur'mu. 2000-2011: Sbornik. Ed. Prilepin, Zakhar, Volynets, Aleksey. Moskva: Tsentrpoligraf, 2016 [“Лимонка" в тюрьму. 2000-2011: Сборник. Ред. Прилепин, Захар, Волынец, Алексей. Москва: Центрполиграф, 2016].

"Limonka" v voynu. Ed. Prilepin, Zakhar. Moskva: Algoritm, 2016 [“Лимонка" в войну. Ред. Прилепин, Захар. Москва: Алгоритм, 2016].

Mannheim, Karl. "Problem pokoleń." Pokolenia albo porządkowanie historii. Transl. Drozdowska-Broering, Izabela, Kałążny, Jerzy, Żytyniec, Rafał. Ed. Orłowski, Hubert. 81-130. Poznań: Wydawnictwo Nauka i Innowacje, 2015.

Matyukhin, Andrey. "Radikal'nyye natsional-patrioticheskiye partii Rossii: protsess stanovleniya." Vestnik MGOU. Seriya: Istoriya i politicheskiye nau$k i$, no. 4, 2015: 172-180 [Матюхин, Андрей. "Радикальные националпатриотические партии России: процесс становления.” Вестник МГОУ. Серия: История и политические науки, № 4, 2015: 172-180].

Popov, Nikolay. "Rossiyskiye i amerikanskiye pokoleniya XX veka: otkuda prishli millenialy?" Monitoring obshchestvennogo mneniya: Ekonomicheskiye i sotsial'nyye peremeny, no. 4, 2018: 309-323 [Попов, Николай. "Российские и американские поколения XX века: откуда пришли миллениалы?” Мониторинг общественного мнения: Экономические и социальные перемеHbl, № 4, 2018: 309-323.

Radayev, Vadim. Millenialy. Kak menyayetsya rossiyskoye obshchestvo. Moskva: Izdatel'skiy dom Vysshey shkoly ekonomiki, 2020 [Радаев, Вадим. Миллениалы. Как меняется российское общество. Москва: Издательский дом Высшей школы экономики, 2020].

"Rozstrzygnięcie plebiscytu młodzieżowe słowo roku 2019 - komentarz Marka Łazińskiego." https://sjp.pwn.pl/mlodziezowe-slowo-roku/haslo/Rozstrzygniecie-plebiscytu-mlodziezowe-slowo-roku-2019-komentarz-Marka-Lazinskiego;6831654.html. Accessed 19 Sep. 2020.

Sieradzan, Przemysław Jan. Aksamitni terroryści. Narodowy bolszewizm w Federacji Rosyjskiej. Warszawa: Dom Wydawniczy “Elipsa," 2008.

Suchanek, Lucjan. Parias i Heros. Twórczość Eduarda Limonowa. Kraków: Wydawnictwo Uniwersytetu Jagiellońskiego, 2001.

William, Strauss, Howe, Neil. Generations. The History of America's Future, 1584 to 2069. New York: William Morrow and Company, 1991.

“'Zakhar Prilepin. Uroki russkogo:' Urok no. 96. Anatomiya geroya: Eduard Limonov." https://www.youtube.com/watch?v=9RTCD0rq0aU. Accessed 23 Sep. 
2020 [““Захар Прилепин. Уроки русского:' Урок № 96. Анатомия героя: Эдуард Лимонов." https://www.youtube.com/watch?v=9RTCD0rq0aU. Дата обращения: 23 сентября 2020].

Zhakovska, Marta. "Fenomen natsional-bol'shevistskogo dvizheniya: ideologicheskiy, sotsial'nyy i kul'turnyy aspekty." Istoriya i sovremennost', no. 1, 2010: 202-222 [Жаковска, Марта. “Феномен национал-большевистского движения: идеологический, социальный и культурный аспекты.” История и современность, по. 1, 2010: 202-222]. 